\title{
Kemampuan Sosial Emosional Anak Usia Dini di Nusa Tenggara Barat
}

\author{
Sri Tatminingsih ${ }^{\bowtie}$ \\ Pendidikan Guru Pendidikan Anak Usia Dini, Universitas Terbuka
}

\begin{abstract}
Abstrak
Masa usia TK merupakan masa bagi seseorang untuk belajar bersosialisasi dan mengelola emosinya. Penelitian ini bertujuan untuk menjabarkan kemampuan sosial emosional anak usia TK di Nusa Tenggara Barat. Penelitian dilakukan dengan metode survey dengan alat pengumpulan data berupa instrument asesmen kemampuan sosial emosional yang terdiri dari 37 item indikator. Teknik pengumpulan data menggunakan observasi dan wawancara. Sampel adalah anak-anak TK kelompok B dari 10 TK Pembina di Kabupaten/Kota di Seluruh NTB dengan total jumlah responden sebanyak 339 anak. Sampel dipilih dengan teknik cluster random sampling. Pengumpulan data dilakukan Bulan Juli-September 2018. Hasil penelitian menunjukkan bahwa rerata kemampuan sosial-emosional anak usia TK kelompok B di NTB berada pada tingkat mampu dengan sedikit bantuan artinya rata-rata anak sudah memiliki potensi untuk berkembang dengan baik namun dalam beberapa hal masih perlu bimbingan dan contoh dari gurunya.
\end{abstract}

Kata Kunci: kemampuan sosial-emosional; anak usia dini; nusa tenggara barat

\begin{abstract}
Kindergarten age is a time for someone to learn to socialize and manage their emotions. This study aims to describe the social emotional abilities of kindergarten age children in West Nusa Tenggara. The research was conducted by survey method with data collection tools in the form of assessment instruments for social emotional abilities consisting of 37 indicator items. The technique of collecting data uses observation and interviews. Samples were kindergarten children in group B from 10 kindergartens in districts / cities throughout NTB with a total number of 339 children. The sample was chosen by cluster random sampling technique. Data collection was carried out in July-September 2018. The results showed that the average social-emotional ability of kindergarten age group B children in NTB was at a level capable with little assistance meaning that on average children had the potential to develop well but in some cases still needed guidance and examples from their teachers.
\end{abstract}

Keywords: social-emotional capability; kindergarten students; west nusa tenggara

Copyright (c) 2019 Sri Tatminingsih

$\triangle$ Corresponding author :

Address : Jl Cabe Raya- Pamulang-Tangerang Selatan

ISSN : 2356-1327 (Media Cetak)

Email : tatmi@ecampus.ut.ac.id

ISSN : 2549-8959 (Media Online) 


\section{PENDAHULUAN}

Anak pada masa usia dini termasuk usia Taman Kanak-kanak (TK) adalah masa yang unik dan strategis. Pada masa ini mereka mulai belajar mengelola emosi dan belajar beradaptasi dengan lingkungan di luar rumah (keluarga). Mereka mulai mengenali diri mereka sendiri dan juga mulai belajar memahami berbagai aturan dalam lingkup sosial masyarakat dimana mereka hidup. Pada masa ini anak mulai mencoba beradaptasi dan dan melakukan berbagai hal yang berkaitan dengan lingkungan di sekitarnya meski tetap berusaha untuk menunjukkan jati diri mereka sendiri. Oleh karena hal tersebut maka TK merupakan salah satu lembaga PAUD formal yang menjadi wadah bagi anak untuk bersosialisasi. Hal ini sejalan dengan tujuan TK, yaitu untuk menstimulasi seluruh potensi anak dan mempersiapkan anak ke jenjang pendidikan selanjutnya serta menjadi wahana bagi anak untuk belajar bersosialisasi.

Dalam Peraturan Pemerintah Nomor 27 Tahun 1990 tentang Pendidikan Prasekolah Bab I Pasal 1 Ayat (2) dinyatakan bahwa "Taman Kanak-kanak adalah salah satu bentuk pendidikan prasekolah yang menyediakan program pendidikan dini bagi anak usia empat tahun sampai memasuki pendidikan dasar (Indonesia, 1990).

Pendidikan TK memiliki peran yang sangat penting untuk pengembangan kepribadian anak, serta untuk mempersiapkan mereka untuk memasuki jenjang pendidikan selanjutnya. Di TK anak-anak diberikan rangsangan pendidikan untuk membantu mengembangkan seluruh potensinya. Tugas utama TK adalah untuk mempersiapkan anak dengan memperkenalkan berbagai pengetahuan, sikap, perilaku, dengan cara yang menyenangkan melalui kegiatan bermain.
TK seyogyanya merupakan tempat bermain yang indah, nyaman, dan gembira bagi anak untuk bersosialisasi dengan teman sebayanya (Fitria, 2013)

TK termasuk lembaga Pendidikan Anak Usia Dini (PAUD) Formal, seperti yang terdapat dalam Peraturan Menteri Pendidikan Nasional No 146 tahun 2014 Pasal 2 ayat 3 yang berbunyi: Layanan PAUD untuk usia 4 (empat) sampai dengan 6 (enam) tahun terdiri atas Taman Kanakkanak (TK) /Raudhatul Athfal (RA)/ Bustanul Athfal (BA), dan yang sederajat. Dalam Permendiknas ini juga dinyatakan bahwa: PAUD adalah suatu upaya pembinaan untuk anak-anak sejak dilahirkan hingga berusia 6 (enam) tahun. Upaya pembinaan ini dilakukan melalui pemberian rangsangan pendidikan untuk membantu atau menstimulasi proses pertumbuhan dan perkembangan baik jasmani dan rohani sehingga anak memiliki kesiapan dalam mengikuti jenjang pendidikan selanjutnya. Selain itu TK juga merupakan wahana bagi anak-anak untuk mendapatkan stimulasi yang tepat guna menemukan dan memperkuat potensinya sejak dini termasuk dalam kemampuan bersosialisasi dan kemampuannya dalam mengendalikan emosinya.

Perkembangan setiap anak memanglah berbeda, karena perkembangan dipengaruhi oleh banyak hal baik itu lingkungan, stimulasi, pola asuh, budaya dan masih banyak lagi faktor yang dapat mempengaruhi perkembangan seorang anak. Namun banyak faktor yang dapat dijadikan acuan oleh orang tua dan guru dalam melakukan observasi terhadap perkembangan anak. Salah satunya adalah dengan mengamati perkembangan anak dengan teori perkembangan yang ada, sehingga orang tua dan guru juga dapat menentukan stimulasi yang cocok untuk anak disesuaikan dengan tahap perkembangan tersebut. Dalam artikel ini 
hanya akan dibahas tentang perkembangan sosial emosional anak usia 5-6 tahun atau anak usia TK kelompok B.

(Papalia, 2008) menyatakan bahwa perkembangan seorang anak dilihat dari keseluruhan aspek perkembangan, yang salah satunya adalah sosial emosional. Menurutnya: perubahan dan stabilitas dalam emosi, kepribadian dan hubungan sosial akan membentuk kemampuan sosial emosional atau disebut sebagai psikososial. Pernyataan tersebut menjelaskan bahwa kemampuan sosial-emosional terdiri dari dua hal, yaitu emosi dan sosial. Keduanya merupakan kemampuan yang saling berkaitan dan saling mempengaruhi.

(Hurlock, 1997: 268) mengemukakan beberapa pola perilaku yang ditunjukan oleh anak-anak pada masa awal, yang meliputi: kerjasama, persaingan, kemurahan hati, hasrat, simpati, empati, ketergantungan, sikap ramah, meniru, dan kelekatan. Hal ini diperkuat dengan hasil penelitian (Agustriana, 2013) menunjukkan bahwa keterampilan sosial anak yang diberikan perlakuan dengan metode edutainment pendekatan permainan lebih tinggi daripada anak yang diberikan perlakuan metode edutainment pendekatan multimedia. Penelitian ini dilakukan dengan metode eksperimen pada anak kelompok A TK Auladuna Bengkulu pada tahun 2013.

Menurut Syamsudin, emosi merupakan suatu suasana yang kompleks ( $a$ complex feeling state) dan getaran jiwa (stid up state) yang menyertai atau muncul sebelum dan sesudah terjadinya suatu perilaku. Dengan kata lain dikatakan bahwa emosi merupakan suatu keadaan yang kompleks, dapat berupa perasaan ataupun getaran jiwa yang ditandai oleh perubahan biologis yang menyertai terjadinya suatu perilaku (Syamsuddin, 2000). Hal ini dipertegas oleh (Tatminingsih, 2016) yang menyatakan bahwa kemampuan emosional adalah kemampuan individu dalam merespon atau bereaksi terhadap suatu peristiwa dihadapinya. Kemampuan ini merupakan keadaan yang kompleks yang dapat berupa getaran atau perasaan jiwa yang ditandai dengan perubahan biologis yang bisa diamati secara langsung melalui perubahan tingkah laku. Reaksi emosi anak sangat kuat. Pada anak usia dini, kemampuan emosional muncul berupa karakteristik: munculnya reaksi emosi pada setiap peristiwa sesuai dengan keinginannya sendiri; mudah berubahnya reaksi emosi anak; reaksi emosinya bersifat individual dan keadaan emosi anak dapat dikenali melalui gejala tingkah laku yang ditampilkannya.

Meskipun kemampuan sosial dan emosi merupakan dua kemampuan yang terpisah namun keduanya merupakan kemampuan yang saling berkaitan dan saling mempengaruhi. Hal ini disampaikan oleh Laura E Berk yang menyatakan bahwa emosi anak-anak adalah sinyal seperti tersenyum, menangis, penuh perhatian, diyakini sangat kuat mempengaruhi orang lain. Demikian pula sebaliknya, dimana reaksi emosional anak-anak juga dipengaruhi oleh perilaku orang lain (Berk, 2006:396).

Kemampuan sosial dan emosional merupakan kemampuan yang saling berkaitan dan saling mempengaruhi. Emosi anak-anak adalah sinyal yang diyakini sangat kuat mempengaruhi orang lain. Demikian pula sebaliknya, dimana reaksi emosional anak-anak juga dipengaruhi oleh perilaku orang lain. Kemampuan sosialemosional yang baik merupakan suatu kemampuan yang perlu dimiliki anak sejak anak masih kecil karena perilaku ini akan sangat mempengaruhi dan menentukan kemampuan anak di kemudian hari. Rapuhnyakemampuan anak dalam berperilaku sosial di lingkungannya akan menghambat perkembangan anak untuk mengendalikan emosinya. Keberhasilan 
individu dalam kehidupannya juga diwarnai oleh keberhasilan individu dalam berinteraksidengan orang lain. Kemampuan sosial emosional yang telah dikembangkan sejak anak masihkecil akan memberikan kontribusi positif pada proses perkembangan atau interaksianak dengan orang lain di kemudian hari (Saodih, 2013:16) Kemampuan sosial-emosional meliputi beberapa aspek, yang oleh Diana $\mathrm{T}$ Dodge dan Laura J Colker, dijabarkan menjadi beberapa komponen berikut.

Tabel 2. Aspek dan Dimensi Kemampuan Sosial-emosional pada Anak ( Dodge and Colker, 2001)

\begin{tabular}{|c|c|}
\hline Aspek & Dimensi \\
\hline $\begin{array}{l}\text { 1. To experience } \\
\text { a sense of self } \\
\text { esteem }\end{array}$ & $\begin{array}{ll}\text { a. } & \text { Mengidentifikasi diri } \\
\text { sendiri sebagai anggota } \\
\text { khusus dari keluarga dan } \\
\text { kelompok budaya } \\
\text { b. Merasa bangga menjadi } \\
\text { keturunan seseorang } \\
\text { danbangga dengan latar } \\
\text { belakangnya } \\
\text { c. Menunjukkan keyakinan } \\
\text { pada kemampuannya } \\
\text { d. Menunjukkan kemandirian } \\
\text { e. Membela hak orang lain }\end{array}$ \\
\hline $\begin{array}{l}\text { 2. To exhibit a } \\
\text { positive } \\
\text { attitude } \\
\text { toward life }\end{array}$ & $\begin{array}{ll}\text { a. } & \text { Menunjukkan kepercayaan } \\
\text { pada orang dewasa } \\
\text { b. Dapat memisahkan diri dari } \\
\text { orang tua } \\
\text { c. Menunjukkan minat dan } \\
\text { berpartisipasi dalam } \\
\text { kegiatan kelas } \\
\text { d. } \\
\text { Berpartisipasi dalam } \\
\text { kegiatan rutin dengan } \\
\text { mudah }\end{array}$ \\
\hline $\begin{array}{l}\text { 3. To } \\
\text { demonstrate } \\
\text { cooperative } \\
\text { prosocial } \\
\text { behavior }\end{array}$ & $\begin{array}{ll}\text { a. } & \text { Mengenali anak-anak dan } \\
\text { orang dewasa } \\
\text { b. Memahami dan merespon } \\
\text { perbedaan } \\
\text { c. menerima tanggung jawab } \\
\text { untuk memelihara } \\
\text { lingkungan kelas } \\
\text { d. membantu orang lain jika } \\
\text { dibutuhkan } \\
\text { e. menghormati hak-hak orang } \\
\text { fain } \\
\text { berbagi mainan dan } \\
\text { peralatan } \\
\text { g. bekerjasama dengan orang } \\
\text { lain dalam mengerjakan } \\
\text { tugas } \\
\text { h. menyelesaikan konflik } \\
\text { secara konstruktif }\end{array}$ \\
\hline
\end{tabular}

Propinsi Nusa Tenggara Barat (NTB) merupakan propinsi yang terletak di antara Pulau Propinsi Bali dan Nusa Tenggara Timur. NTB terdiri dari dua Pulau besar, yaitu Pulau Lombok dan Pulau Sumbawa. Lombok sebagian besar dihuni oleh Suku Sasak dan Sumbawa oleh Suku etnis Bima dan Sumbawa dan mayoritas Penduduknya beragama Islam.

Berdasarkan pengamatan Penulis, kehidupan sosial masyarakat NTB masih cukup kental dalam menjalankan adat istiadatnya, misalnya masih tampak kegiatan Nyongkolan (arak-arakan pernikahan). Meskipun terdapat lebih dari satu suku pendatang namun masyarakat NTB tetap menjunjung tinggi toleransi. Hal ini terlihat dari ketentraman dan ketenangan masing-masing suku menjalankan ibadahnya. Misal saat suku Bali menjalankan ibaah di Pura, warga sekitar turut menjaga dan mengatur lalu lintas.

Berdasarkan uraian di atas maka peneliti ingin mengetahui gambaran tentang kemampuan sosial emosional anak di NTB karena mereka hidup dalam wilayah yang termasuk beragam namun di dalam rumahnya mereka kebanyakan masih menerapkan adat istiadat yang dianut orang tuanya.

\section{METODOLOGI}

Penelitian ini menggunakan metode survey dengan paradigma kuantitatif deskriprif. Data dikumpulkan dengan teknik observasi dan wawancara menggunakan instrument asesmen kemampuan sosialemosional anak yang telah dikembangkan oleh peneliti. Survaey dilakukan dengan mengamati setiap anak untuk mendapatkan gambaran perilaku yang terdapat dalam insdikator kemampuan sosialemosionalnya. Penelitian dilaksanakan pada Bulan Juli - September 2018. Populasi adalah anak-anak TK B di seluruh TK Pembina di NTB. Mengingat luasnya wilayah penelitian dan banyaknya jumlah TK Negeri (TK Pembina), yaitu minimal satu TK dalam satu kecamatan maka jumlah TK Pembina yang dijadikan sampel adalah sebanyak 10 TK yang masing-masing mewakili satu kabupaten/Kota. Sampel 
dipilih dengan teknik cluster random sampling, yaitu dari Setiap Kabupaten, hanya diambil satu TK Pembina. Sampel adalah anak-anak TK B di 10 TK Pembina di NTB. Setiap TK diwakili oleh maksimal 2 kelas Kelompok B dengan jumlah peserta didik 20 anak/kelas sehingga jumlah responden tiap TK sebanyak 40 anak. Total jumlah responden sebanyak 400 anak. Data yang terkumpul kemudian diolah dengan statistik sederhana dengan menghitung total nilai skor pada setiap anak lalu dihitung rata-rata dan persentasenya. Data tersebut kemudian dianalisis dan dijabarkan secara deskriptif dan dilakukan pembahasan dengan menggabungkan bersama hasil wawancara dengan guru. Hasil asesmen kemampuan sosial-emosional terhadap 400 anak, hanya sebanyak 339 saja yang layak untuk diolah dan dianalisis lebih lanjut..

\section{HASIL DAN PEMBAHASAN}

\section{Penjelasan tentang Responden}

Seperti telah sidampaikan dalam metode penelitian. Jumlah responden sebanyak 400 anak, namun data yang dapat diolah lebih lanjut sebanyak 339 saja. Berikut adalah rincian jumlah anak per TK.

Tabel 1. Data Jumlah Responden Per TK

\begin{tabular}{llc}
\hline No & \multicolumn{1}{c}{$\begin{array}{c}\text { Nama TKN } \\
\text { Pembina }\end{array}$} & $\begin{array}{c}\text { Jumlah } \\
\text { anak }\end{array}$ \\
\hline 1. & Ampenan & 36 \\
2. & Cakra & 39 \\
3. & Lombok Barat & 40 \\
4. & Pemuda & 40 \\
5. & Lombok tengah & 40 \\
6. & Kab Sumbawa & 40 \\
7. & Empang & 40 \\
8. & Kota Bima & 24 \\
9. & Kab Bima & 20 \\
10. & Dompu & 20 \\
\hline \multicolumn{3}{c}{ Jumlah } \\
\hline
\end{tabular}

Data tentang jenis kelamin anak-anak yang menjadi responden terdiri dari 198 anak perempuan dan 141 anak laki-laki. Data tentang usia responden dilihat dari tanggal lahir yang dituliskan dalam instrument asesmen. Usia responden pada saat pengambilan adalah antara 4 tahun 10 bulan hingga- 6 tahun 7 bulan. Anak yang termuda berusia 4 tahun 10 bulan, jumlahnya sebanyak 7 anak. Sedangkan anak-anak yang tertua berusia 6 tahun 7 bulan, jumlahnya ada 19 anak. Hal ini menunjukkan bahwa anak-anak pada kelompok B di TK Pembina yang menjadi sampel, termasuk anak-anak yang berusia matang atau memiliki usia yang tepat untuk usia kelompok B. Meskipun ada 7 anak yang usianya kurang dari 5 tahun namun porsinya hanya sedikit. Dengan demikian, diharapkan perkembangan sosialemosionalnya sesuai dengan tugas perkembangan anak-anak yang normatif.

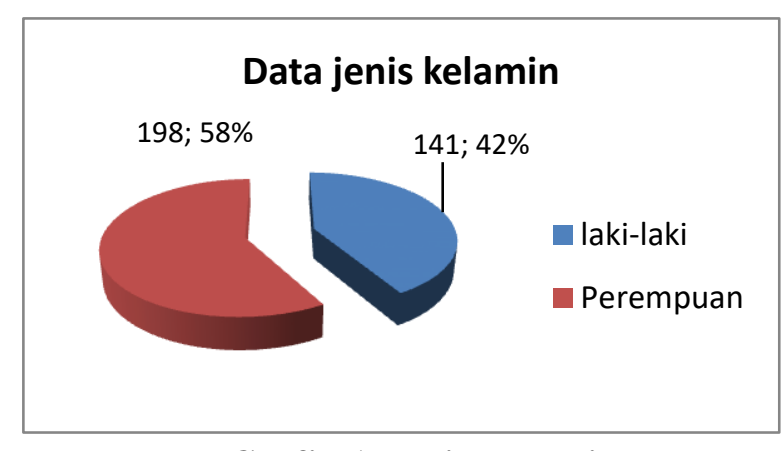

Grafik 1. Jenis Kelamin

Selain data tentang jenis kelamin dan usia, dijaring pula data tentang wali yang mengasuh setiap responden dan tempat tinggal mereka. Data ini dianggap penting karena kemampuan sosial emosional anak juga dipengaruhi oleh lingkungan tempat anak tinggal. , Sebagian besar anak-anak diasuh oleh orang tuanya, yaitu sebanyak 167 anak atau sebanyak 49\%. Diasuh oleh kakek atau neneknya sebanyak 89 anak (26\%), diasuh keluarga lain seperti paman atau bibi sebanyak 54 anak (16\%) dan diasuh oleh orang lain (diadopsi dan panti asuhan) sebanyak 29 anak (9\%). Hampir sebagian besar anak bertempat tinggal tidak jauh dari lingkungan TK (1-3 kilometer dari TK), yaitu sebesar 92\% dan Responden yang tempat tinggalnya 3-5 kilometer sebanyak $5 \%$ dan responden yang tinggal jauh dari lingkungan TK (> 5 kilometer) sebanyak 3\%. Guna memperjelas jabaran 
ini, disajikan pula dalam bentuk grafik berikut ini.

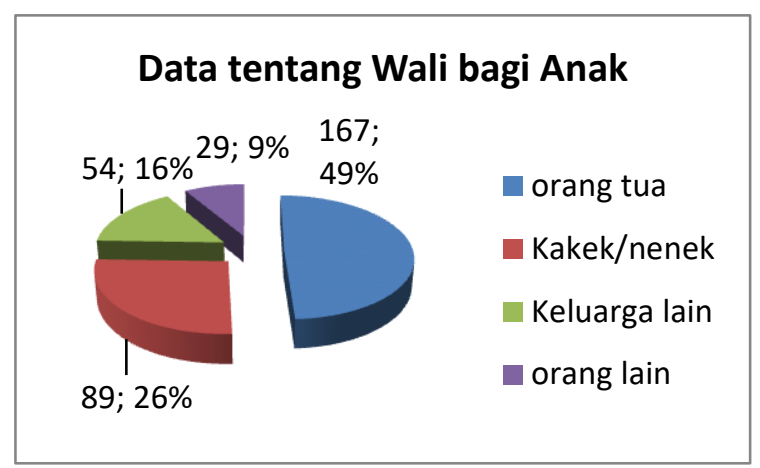

Grafik 2 Data tentang Wali Anak

\section{Kemampuan Sosial-emosional anak}

Kemampuan sosial-emosional anakanak TK B di Nusa Tenggara Barat ini diukur menggunakan instrument asesmen kemampuan sosial-emosional yang terdiri dari 37 item indicator. Indikator ini merupakan penjabaran dari 17 dimensi kemampuan sosial-emosional menurut ( Dodge and Colker, 2001). Instrumen kemampuan sosial-emosional ini telah diuji validitas dan reliabilitasnya.

Hasil uji validitas menunjukkan bahwa terdapat korelasi positif sebesar 0,96014 antara skor butir dengan skor total, hal ini menunjukkan tingginya konsistensi antara hasil ukur keseluruhan instrumen dengan hasil ukur butir instrumen tinggi atau dapat dikatakan bahwa butir instrumen konvergen dengan butir-butir lain dalam mengukur suatu konsep atau konstruk yang hendak diukur sebesar 0,96014.

Hasil uji reliabilitas menunjukkan bahwa nilai Alpha Cronbach dari perangkat tes tersebut adalah 0,977 yang berarti perangkat instrumen asesmen tersebut sangat reliabel untuk digunakan sebagai alat ukur yang baik untuk mengukur kemampuan sosial-emosional anak. Kedua hasil tersebut menunjukkan bahwa instrument asesmen kemampuan sosialemosional valid dan reliable digunakan untuk mengukur kemampuan sosialemosional anak TK Kelompok B.

\begin{tabular}{|c|c|c|}
\hline $\begin{array}{c}\text { Cronbach's } \\
\text { Alpha }\end{array}$ & $\begin{array}{c}\text { Cronbach's Alpha } \\
\text { Based on } \\
\text { Standardized } \\
\text { Items }\end{array}$ & N of Items \\
\hline, 977 &, 979 & 37 \\
\hline
\end{tabular}

Hasil asesmen terhadap kemampuan sosial-emosional anak di TK sampel secara keseluruhan disajikan dalam bentuk tabel dan grafik berikut ini.

Tabel 2 Skor Kemampuan Sosial-emosional

Anak TK B di Nusa Tenggara Barat

\begin{tabular}{lcccl}
\hline No & $\begin{array}{c}\text { Rentang } \\
\text { Skor }\end{array}$ & $\Sigma$ & $\%$ & Keterangan \\
\hline 1. & $37-55,4$ & 39 & 12 & $\begin{array}{l}\text { Belum } \\
\text { berkembang } \\
\text { dengan baik }\end{array}$ \\
\hline 2. & $55,5-73,9$ & 115 & 34 & $\begin{array}{l}\text { Sudah mulai } \\
\text { berkembang }\end{array}$ \\
\hline 3. & $74-92,4$ & 102 & 30 & Berkembang \\
\hline 4. & $92,5-111$ & 83 & 24 & $\begin{array}{l}\text { Berkembang } \\
\text { dengan baik }\end{array}$ \\
\hline & Total & 339 & 100 & \\
\hline
\end{tabular}

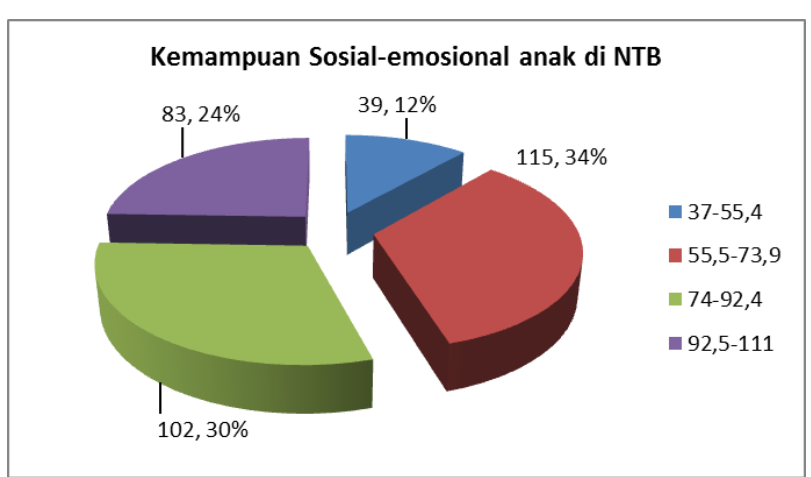

\section{Grafik 3.Kemampuan Sosial-emosional Anak TK di NTB}

Berdasarkan data tersebut tampak bahwa anak-anak TK di NTB pada dasarnya memiliki kemampuan sosialemosional seperti juga anak-anak TK lainnya. Artinya adalah mereka semua memiliki potensi kemampuan sosialemosional yang sudah mulai berkembang hingga berkembang dengan baik dan potensi ini dapat ditingkatkan melalui berbagai stimulasi yang positif. Hal ini sejalan dengan hasil penelitian (Ananda and Fadhilaturrahmi, 2018) yang menyatakan 
bahwa perkembangan kemampuan sosialemosional anak yanag semula mengalami hambatan dapat mengalami peningkatan setelah distimulasi dengan memberikan permainan kolaboratif. Penelitiannya dilakukan di Kelompok Bermain Tuanku Tambusai.

Data tersebut menggambarkan bahwa sebagian besar berada pada rentang skor 55,5 hingga 92,4 yaitu berjumlah 257 anak atau sebesar 64\%. Anak-anak yang memiliki skor di bawah 55,5 sebesar $12 \%$ atau ada sebanyak 39 anak. Sedangkan anak yang memiliki skor tinggi, antara 92,5 hingga yang tertinggi 111 ada sebanyak 83 anak atau sebesar $24 \%$. Skor ini diperoleh dari banyaknya indikator kemampuan sosial-emosional yang terdapat dalam instrument asesmen kemampuan sosialemosional, yaitu sebanyak 37 indikator. Skor penilaian diberikan mulai dari rentang 1 hingga 3. Artinya adalah semakin tinggi skornya maka anak semakin baik memiliki kemampuan sosial-emosionalnya. Hasil penelitian ini memperkuat pendapat Peter Moss yang menyatakan bahwa pada usia prasekolah, kemampuan sosial-emosional anak-anak pada umumnya seperti kurva normal, dimana sebagian besar anak memiliki kemampuan rata-rata atau dominan dan hanya sebagian kecil yang rendah atau tinggi (Moss, 2019). Skor kemampuan ini masih sangat mungkin meningkat jika distimulasi melalui berbagai cara oleh orang dewasa. Hal ini sejalan dengan penelitian Rezka Arina Rahma, dkk., yang menyatakan bahwa kemampuan sosial-emosiaonal anak dapat terus ditingkatkan melalui stimulasi di Lembaga pendidikan maupun sekolah di rumah (home schooling), yaitu dengan menyediakan berbagai alat permainan dan kegiatan bermain yang dapat memfasilitasi anak untuk mengeksplor dan mengembangkan kemampuan sosial- emosionalnya (Rezka A. Rahma, dkk, 2018).

Hasil penelitian juga menunjukkan bahwa ada $12 \%$ anak yang belum berkembang dengan baik. Setelah dianalisis lebih dalam lagi melalui wawancara dengan guru, diperoleh penjelasan bahwa anakanak yang memiliki skor rendah ini adalah anak-anak yang baru mulai masuk TK pada usia 5 tahun lebih dan langsung masuk ke TK B tanpa melalui TK A terlebih dahulu. Selain itu dari 39 anak tersebut 14 diantaranya adalah anak-anak yang sangat pendiam, jarang berbicara dan masih ditunggui oleh pengantarnya selama bermain dan belajar di TK. Menurut guru, mereka memang belum mengenal lingkungan sekolah. Sembilan anak lainnya merupakan anak yang tinggal dengan kakek/neneknya karena kedua orang tuanya bekerja di luar daerah NTB baik di luar negeri ataupun di wilayah lain di Indonesia. Kesembilan anak ini diasuh dan dirawat oleh kakek/neneknya sejak masih bayi bahkan ada 3 anak yang sudah ditinggal oleh orang tuanya sejak dilahirkan. Hal ini merupakan salah satu penyebab anak menjadi kurang percaya diri dan banyak kemampuan sosial-emosionalnya tidak muncul saat diobservasi. Kemampuan yang tidak muncul itu diantaranya adalah aspek/dimensi: menunjukkan kepercayaan pada orang dewasa; dapat memisahkan diri dari orang tua; menunjukkan minat dan berpartisipasi dalam kegiatan kelas dengan rincian indikator, yaitu: 1) memperagakan cara meminta bantuan pada orang dewasa, 2) mengikuti saran guru ketika menemui masalah, 3) tidak ditunggui orang tua saat di sekolah, 4) berpartisipasi dalam setiap kegiatan di sekolah dan 5) berani mencoba kegiatan baru tanpa diperintah. Hasil penelitian ini hampir sama dengan penelitian yang dilakukan oleh Margaret Sims dan Karl Brettig yang menyatakan bahwa cara hidup orang tua atau keluarga 
terdekat anak sangat mempengaruhi perilaku anak, termasuk sosial-emosional. Misalnya Ibu yang pemabuk akan menyebabkan anak-anak menjadi tidak percaya diri, penakut dan cenderung curiga pada lingkungannya (M.Sim, \& K.Brettig, 2018). Meskipun demikian, kemampuan ini masih bisa diperbaiki mengingat usia anak yang masih sangat muda. Upaya memperbaiki ini harus dilakukan melalui kolaborasi dengan berbagai pihak, yaitu pemerintah, keluarga, sekolah daan masyarakat. Misalnya dengan menyusun kebijakan untuk peningkatan kesehatan mental atau regulasi stimulasi perkembangan sosial-emosional, pengembangan kurikulum, penyediaan sarana dan prasarana dan memberi kesempatan pada anak untuk mendapatkan pengalaman sosial agar anak dapat mengelola emosinya secara mandiri (Shulamit N. Ritblatt, et.al., 2017)

Delapan anak yang mendapat skor pada rentang terendah ini, ternyata adalah anak-anak yang memang memilki kekhususan atau anak dengan kebutuhan khusus. Ke delapan ini menyebar di 6 TK. Kekhususan yang dimiliki anak-anak ini adalah autism sebanyak 6 anak, bibir sumbing 1 anak, dan gagap 1 anak. Guru menjelaskan bahwa sebagai TK negeri atau TK percontohan, mereka harus melaksanakan pendidikan inklusi yang artinya mereka tetap harus menerima anak dengan kebutuhan khsusus. Meskipun demikian, saat mereka menerima anak-anak ini untuk bersekolah di tempat mereka, pihak sekolah memberikan persyaratan khusus pada orang tua/wali anak. Beberapa persyaratannya adalah1) anak harus diantar dan ditunggui oleh orang tua/wali/ pengantar; 2) Orang tua/wali tidak menuntut anak untuk bisa mencapai kompetensi seperti anak-anak normatif; 3) Jika anak sangat mengganggu proses pembelajaran, maka orang tua bersedia bila anaknya diminta berhenti dari sekolah. Kesepakatan tersebut sengaja dibuat oleh pihak sekolah untuk melindungi anak tersebut dan juga menjaga hak anak-anak lainnya. Kondisi anak-anak yang memiliki kekhususan ini juga dialami oleh Amerika Serikat yang berada di urutan ke 26 dari 29 negara "kaya" yang memiliki anak dengan kemampuan nonnormatif. Upaya yang dilakukan oleh USA serta negara-negara lainnya dan juga Lembaga Internasional seperti Bank Dunia, Organisasi Kesehatan Dunia dan UNICEF, adalah dengan menyediakan pendidikan inklusi bagi anakanak tersebut. Derngan demikian, anakanak yang merupakan investasi masa depan bagi suatu bangsa dapat distimulasi dengan sebaik-baiknya termasuk kemampuan sosial-emosionalnya (Klaus, 2016).

Data tersebut juga menunjukkan bahwa anak-anak di NTB cukup banyak yang memiliki kemampuan sosialemosional yang tinggi, yaitu dengan skor 92,5 hingga 111. Jumlah anak yang mencapai skor ini sebanyak 83 anak atau sebesar 24\%. Jumlah yang cukup banyak dari 339 responden. Setelah didalami melalui wawancara mendalam (deep interview) dengan guru dan kepala $\mathrm{Tk}$, maka diperoleh penjelasan bahwa anakanak yang memiliki skor tinggi ini adalah anak-anak yang hampir semuanya adalah mereka yang sudah masuk TK sejak usia 4 tahun atau dari TK A. Bahkan ada 32 anak yang sudah masuk sejak usia kelompok bermain atau usia 3 tahun. Hal inimenjadikan mereka anak-anak yang sudah terbiasa dengan lingkungan sekolah dan aturan yang berlaku di sekolah.Mereka juga memilki rasa percaya diri yang cukup tinggi, sudah mengenal personil di lingkungan sekolah dan sudah terbiasa mengikuti kegiatan bermain dan belajar pada waktu yang terjadwal.10 anak dengan skor tertinggi (skor 111) adalah anak-anak yang memang pada saat akhir tahun di TK 
A nya mendapat prestasi atau unggulan.Tujuh diantaranya adalah ketua kelas. Dari sisi keluarga, anak-anak yang mendapat skor tinggi ini cukup bervariasi. Sebagian dari mereka memang diasuh oleh orang tuanya langsung 62 anak, diasuh kakek/neneknya 7 anak dan diasuh oleh keluarga lainnya sebanyak 14 anak. Hal tersebut menggambarkan bahwa sesungguhnya wali tidak terlalu mempengaruhi kemampuan sosialemosional anak selama proses pendidikan di rumah sejalan dengan pendidikan di sekolah. Hasil ini sejalan dengan hasil penelitian yang dilakukan oleh Robbiyah, Diyan Ekasari dan Ramdhan yang menyatakan bahwa kecerdasan sosial sangat dipengaruhi oleh didikan dan dorongan yang diberikan oleh ibu. Setiap ibu memiliki cara tersendiri untuk menstimulasi perkembangan anak mereka. Artinya adalah bahwa kemampuan sosial dan emosional dipengaruhi oleh pola asuh yang dilakukan oleh keluarga, khususnya ibu (Robbiyah, Ekasari and Witarsa, 2018).

\section{KESIMPULAN}

Hasil penelitian ini menunjukkan bahwa gambaran kemampuan sosialemosional anak-anak TK kelompok B di Nusa Tenggara Barat memiliki potensi kemampuan sosial-emosional yang sudah mulai berkembang hingga berkembang dengan baik atau sama dengan kemampuan sosial-emosional anak usia 5-6 tahun pada umumnya. Meskipun ada beberapa anak berada pada tahap belum berkembang dengan baik namun seiring bertambahnya usia dan proses pendidikan yang dijalaninya maka kemampuan sosial-emosionalnya kemungkinan akan meningkat sesuai tingkat perkembangannya. Kemampuan sosial-emosional ini masih dapat ditingkatkan melalui berbagai stimulasi yang tepat oleh guru dan orang tua sehingga peran guru dan orang tua sangat penting dan tidak dapat digantikan oleh apapun termasuk alat permainan atau media.

\section{UCAPAN TERIMA KASIH}

Terimakasih kami ucapkan kepada semua pihak yang berperan dalam proses penelitian ini. Terutama kepada civitas akademika Universitas Terbuka Mataram dan kepala TK, guru dan anak didik di sepuluh TK Negeri Pembina di NTB.

\section{DAFTAR PUSTAKA}

Dodge and Colker. (2001). The Creative curriculum for Early Chilhood. Washington: Teaching Strategies. Inc. Agustriana, N. (2013). Pengaruh Metode Edutainment dan Konsep Diri terhadap Keterampilan Sosial Anak (Eksperimen di Kelompok A TK Auladuna Bengkulu tahun 2013). Jurnal. Pendidikan Usia Dini Volume 7 No. 2 November . Jakarta: Universitas negeri jakarta.

Ananda and Fadhilaturrahmi. (2018).

Peningkatan Kemampuan Sosial Emosional melalui Permainan Kolaboratif pada Anak KB. Jurnal Obsesi: Jurnal Pendidikan Anak Usia Dini Vol 2 No 1. Riau: Universitas Pahlawan Tuanku Tambusai.

Berk, L. E. (2006:396). Child Development. Seven Ed. Boston: Pearson International Edition.

Fitria, A. (2013). Pendidikan Taman

Kanak-kanak. Jakarta: Kompasiana: https://www.kompasiana.com/anis_fit ria/55207d42a33311b14646cfad/pend idikan-taman-kanak-kanak-tk.

Hurlock, E. B. (1997: 268). Child Development 6thEd. Tokyo: McGraw Hill Inc.International Student Ed.

Indonesia, P. (1990). Peraturan Pemerintah Republik Indonesia Nomor 27 tahun 1990 tentang Pendidikan Prasekolah. 
Jakarta: Kementerian Sekertaris negara Indonesia.

Klaus, S. (2016). Early-ChildhoodDevelopment Research Is 'Unassailable'. Journal of Education Week Commentary Vol. 35, Issue 25, 21-25.

M.Sim, \& K.Brettig. (2018). Early childhood education and early childhood development: Do the differences matter? . Journal of Power and Education 0 (0), 1-13.

Moss, P. (2019). Alternative Narratives in Early Childhood,. London: UCL Institute of Education, University College London.

Papalia, D. E. (2008). A Child's World. New York: McGraw-Hills Publishing Company.

Rezka A. Rahma, dkk. (2018). The Social Emotional Development of Homeschooling Children. Journal of Nonformal Education, JNE Vol 4 (2), 151-160.

Robbiyah, Ekasari and Witarsa. (2018). Pengaruh Pola Asuh Ibu terhadap Kecerdasan Sosial Anak Usia Dini di TK Kenanga Kabupaten Bandung Barat. Jurnal Obsesi: Jurnal Pendidikan Anak USia Dini Vol 2 No 1 . Riau: Universitas Pahlawan Tuanku Tambusai.

Saodih, E. (2013:16). Pengembangan Prilaku Sosial-Emosional Anak Taman Kanak-Kanak Melalui Layanan Bimbingan Konseling Perkembangan. Bandung : DirektoriFIP-Jur PGTK.

Shulamit N. Ritblatt, et.al. (2017). Investing in the Early Childhood Mental Health Workforce Development: Enhancing Professionals' Competencies to Support Emotion and Behavior Regulation in Young Children. Journal of Brain Sciences 7 (120), 119.
Syamsuddin. (2000). Psikologi Pendidikan (edisi revisi). Bandung: Remaja Rosda Karya.

Tatminingsih, S. (2016). Pengembangan model Pembelajaran Berbasis Permainan Komprehensif untuk Meningkatkan Kemampuan Kognitif dan Sosial-emosional Anak (Studi di TK Islam Fithria Jakarta Selatan), Disertasi. Jakarta: Universitas Negeri Jakarta. 